\title{
Miocene Marine Diatoms from the Kirkwood Formation, Atlantic County, New Jersey
}

\section{U.S. GEOLOGICAL SURVEY BULLETIN 1769}





\section{Miocene Marine Diatoms from the Kirkwood Formation, Atlantic County, New Jersey}

\section{By GEORGE W. ANDREWS}

Early and middle Miocene marine diatom assemblages from the northern part of the Atlantic Coastal Plain region and their stratigraphic significance 


\title{
DEPARTMENT OF THE INTERIOR DONALD PAUL HODEL, Secretary
}

\author{
U.S. GEOLOGICAL SURVEY \\ Dallas L. Peck, Director
}

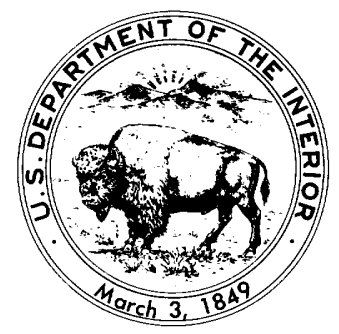

For sale by the Books and Open-File Reports Section, U.S. Geological Survey, Federal Center, Box 25425, Denver, CO 80225

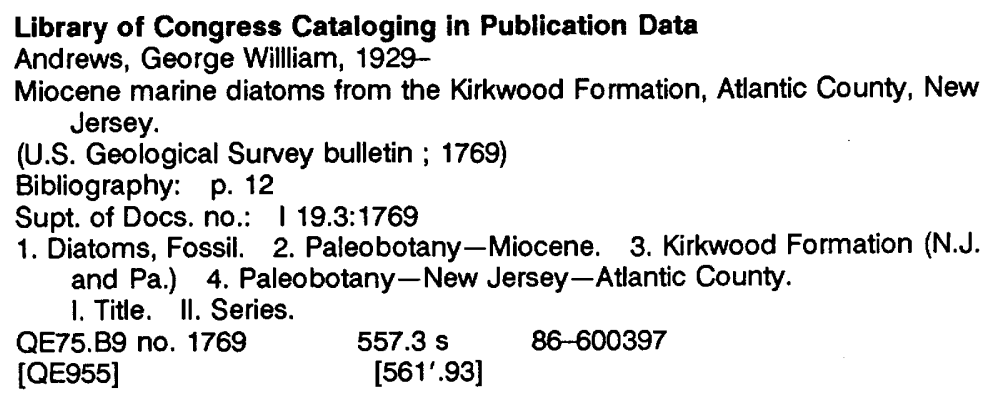




\title{
CONTENTS
}

\author{
Abstract 1 \\ Introduction 1 \\ Location of deposit 2 \\ Stratigraphy of deposit 2 \\ Previous work 2 \\ Summary of investigation 5 \\ Diatom biostratigraphy 5 \\ Age of diatom assemblages and Miocene strata 7 \\ Paleoecology 8 \\ Systematic paleontology 8 \\ References cited 12

\section{PLATES} \\ [Plates follow references cited] \\ 1. Actinoptychus, Aulacodiscus, Delphineis. \\ 2. Rhaphoneis. \\ 3. Sceptroneis, Rhaphoneis, Delphineis.
}

\section{FIGURES}

1. Index map showing Atlantic City Girl Scout Camp 4 borehole site, Atlantic County, N.J. 3

2. Chart showing stratigraphic position and depth of samples studied for diatoms in the Atlantic City Girl Scout Camp 4 borehole, Atlantic County, N.J. 4

\section{TABLE}

1. Stratigraphic occurrence of marker diatoms in the Atlantic City Girl Scout Camp 4 borehole core samples, Atlantic County, N.J. 6 



\title{
Miocene Marine Diatoms from the Kirkwood Formation, Atlantic County, New Jersey
}

\author{
By George W. Andrews
}

\section{Abstract}

Although diatoms have been known from the New Jersey Miocene rocks for nearly 100 years, no serious effort has been made previously to use diatoms for modern biostratigraphic correlation in this region. Samples from a core taken on the Atlantic City Girl Scout Camp 4 (ACGSC-4) property, about 3.2 miles $(5.3 \mathrm{~km})$ northwest of Mays Landing, Atlantic County, New Jersey, have been examined for diatoms, and the results are herein reported.

Diatoms occur in this core in a single sample from a depth of 293 feet $(89 \mathrm{~m})$ and in an upper interval from a depth of 155 to 239 feet $(47$ to $73 \mathrm{~m}$ ). The lower sample contains a poorly preserved diatom assemblage, but fragments of Actinoptychus heliopelta were present. This diatom suggests the correlation of this bed with East Coast Diatom Zone 1 of Andrews (1978, Marine diatom sequence in Miocene strata of the Chesapeake Bay region, Maryland: Micropaleontology, v. 24, no. 4, p. 371-408, pls. 1-8) and a late Burdigalian age (late early Miocene). This bed is equivalent to the oldest part of Lithologic Unit 3 of the Calvert Formation in the Chesapeake Bay region of Maryland.

The lower diatomaceous bed is separated from the upper diatomaceous interval by a 54-foot (16-m) section that is barren of diatoms in the core. The upper interval contains marine marker diatoms indicative of East Coast Diatom Zone 2 of Andrews (ibid.) and a Langhian age (early middle Miocene). This interval correlates well with the upper part of Lithologic Unit 3 and Units 4 to 9 of the Calvert Formation of Maryland. A new marine diatom species having potential value as a marker diatom, Rhaphoneis praeparilis, is described from this interval. The barren interval between the two diatomaceous levels represents approximately 1 million years of geologic time.

The upper diatomaceous interval in the core is found in approximately the upper 25 percent of the Kirkwood Formation. The lower diatomaceous bed occurs about 54 feet below the upper bed. The remainder of the Kirkwood (approximately the lower 60 percent) cannot be dated by diatoms, but it must represent an interval of early Miocene deposition unknown farther south along the Atlantic Coastal Plain. Planktic foraminifera from a depth of 473 feet (144 m) indicate an age of about 19.0 to $21.8 \mathrm{Ma}$ (Zone N5) near the base of the Kirkwood Formation.

\section{INTRODUCTION}

The sedimentary rocks of the Atlantic Coastal Plain of New Jersey were recognized in the mid-eighteenth century, and an excellent summary of the early stratigraphic investigations and nomenclature is given by Spangler and Peterson (1950, p. 7-15). Cook (1868, p. 294-298) recognized the occurrence of a Miocene fossiliferous deposit in New Jersey in his discussion of the "Shiloh Marl" from Cumberland County. The earliest report on Miocene diatoms from New Jersey is that published by Kain and Schultze (1889) on the diatoms from an artesian well in Atlantic City.

The older of the two Miocene formations now recognized in New Jersey is the Kirkwood Formation, originally described by Knapp (1904, p. 81). The Kirkwood Formation crops out in a northeasterly trending irregular band from Shiloh in the southwest to Asbury Park in the northeast, as shown by Richards and Harbison (1942, fig. 1). It dips through the subsurface to the southeast and probably reaches its maximum thickness in New Jersey near Wildwood and Cape May. The Kirkwood Formation contains an extensive molluscan fauna, which Richards and Harbison (1942) described. They correlated the lower part of the Kirkwood Formation with the Calvert and Choptank Formations of Maryland and the upper part of the Kirkwood with the St. Marys Formation of Maryland. More recently, Isphording (1970) studied the mineralogy and lithology of the Kirkwood Formation and subdivided the formation into the Alloway Clay Member, Asbury Park Member, and Grenloch Sand Member. The delineation of these members seems to be, at least in part, facies related.

Goldstein (1974) made an extensive palynological study of the Kirkwood Formation. He delineated five subsurface palynological phases in the Kirkwood Formation, correlating his oldest Phase I with the Tampa Formation of Georgia and Florida, his Phase II with the Hawthorn Formation of South Carolina and Georgia, his Phase III with the Calvert Formation of Maryland, his Phase IV with the Choptank Formation of Maryland, and his Phase V with the St. Marys Formation of Maryland. 
He further correlated his Phase III palynological unit with the Asbury Park and Alloway Clay Members of the Kirkwood Formation of Isphording (1970) and with the occurrence of the diatom Actinoptychus heliopelta from the lower part of the Calvert Formation in Maryland. Relating Goldstein's study of the pollen biostratigraphy precisely to the diatom biostratigraphy of the Atlantic City Girl Scout Camp (ACGSC-4) borehole core is difficult. The diatomaceous section herein studied may be equivalent to palynological Phase III of Goldstein (1974), but most of this diatomaceous section is distinctly younger than the Actinoptychus heliopelta zone.

This report represents the first attempt to correlate the Miocene formations of New Jersey with the East Coast Diatom Zones proposed by Andrews (1978) for the Chesapeake Bay region of Maryland. Correlation of the Kirkwood Formation with the Miocene formations of Maryland and Virginia was made in a general way by many of the early diatom workers. However, with the establishment of a system of diatom zonation, this correlation now should be more precise than has previously been possible.

\section{LOCATION OF DEPOSIT}

The diatoms studied for this report were derived from cores taken from a borehole drilled approximately 3.2 miles $(5.3 \mathrm{~km})$ northwest of Mays Landing, Atlantic County, N.J. The borehole, which was drilled by the U.S. Geological Survey (USGS), was spudded on August 7, 1984. Samples were collected under the supervision of James P. Owens (U.S. Geological Survey, Reston, Va.). The borehole was drilled on the property of Atlantic City Girl Scout Camp No. 4 and will be referred to as ACGSC-4 subsequently in this report. The location of the borehole site is approximately 0.6 mile $(1.0 \mathrm{~km})$ south and 0.7 mile $(1.1 \mathrm{~km})$ west of the northeast corner of the Dorothy 71/2-minute quadrangle (U.S. Geological Survey, 1972). The location of the borehole site is shown on figure 1. The borehole was drilled near the upper edge of a low escarpment at the margin of the modern flood plain of the Great Egg Harbor River, and the altitude of the wellhead is approximately 50 feet $(15 \mathrm{~m})$. The borehole has been converted into a water well by the property owners (James P. Owens, oral commun., 1985).

\section{STRATIGRAPHY OF DEPOSIT}

The ACGSC -4 borehole was drilled to a total depth of 945 feet $(288 \mathrm{~m})$, but this report discusses only the diatomaceous stratigraphic section of the Miocene Kirkwood Formation. The pertinent part of a lithologic and gamma ray log for this borehole (adapted from a log prepared by James P. Owens, U.S. Geological Survey, Reston, Va.) is shown in figure 2. The upper part of the hole penetrated sandy surficial materials and the Cohansey Sand of probable Miocene age to a depth of approximately 150 feet ( $46 \mathrm{~m}$ ) (James P. Owens, oral commun., 1985). The Kirkwood Formation, a sequence of alternating clays, sandy clays, and sands, was penetrated to a depth of approximately 484 feet $(148 \mathrm{~m})$ (James P. Owens, oral commun., 1985). Part of this Kirkwood section has proven to be diatomaceous. Below 484 feet $(148 \mathrm{~m})$, the borehole penetrated sands of Eocene age. These sands were not examined for diatoms because the sandy deposits of pre-Miocene age are not known to contain diatoms in the Atlantic Coastal Plain.

\section{PREVIOUS WORK}

The earliest report on the fossil diatoms of New Jersey was made by Kain and Schultze (1889) on the samples derived from an artesian well at Atlantic City, N.J. They published a list of diatom species derived from samples taken between 387 and 638 feet (118 and $195 \mathrm{~m}$ ) in well depth, and they named and described several new diatom species. They noted the similarity of these New Jersey diatoms to those in the Miocene deposits of Maryland and Virginia, but they did not speculate extensively on any stratigraphic correlation. Their paper is of importance to diatom biostratigraphy in that it contains the original description of Delphineis novaecaesaraea (Kain and Schultze) Andrews, recognized by Andrews (1978) as an important Miocene marker diatom.

Woolman (1891) described more extensively the stratigraphic section in the artesian wells at Atlantic City. He suggested the correlation of the diatomaceous beds in the Atlantic City wells with a similar bed in an artesian well at Cambridge, Md. He reported that the diatom species were relatively consistent throughout a 275 -foot (84-m) section, and he recognized Paralia sulcata as one of the most frequent diatoms. Woolman (1892) again reported the occurrence of a continuously diatomaceous section between depths of 382 and 697 feet (116 and 213 $\mathrm{m})$ in the Atlantic City wells. He also reported the occurrence of Actinoptychus heliopelta at depths of 625 to 675 feet (191 to $206 \mathrm{~m}$ ) at Atlantic City and in outcrops near Shiloh, N.J. He made a tentative correlation with the deposit cropping out along the Patuxent River near Nottingham, Md., but his suggestions of correlation with deposits at Bermuda Hundred and Petersburg, Va., are no longer tenable. Boyer (1895) reported on a diatom assemblage from a well near Wildwood in southern New Jersey. However, this was in a shallow deposit dominated by freshwater species and probably of Pleistocene or Holocene age. 


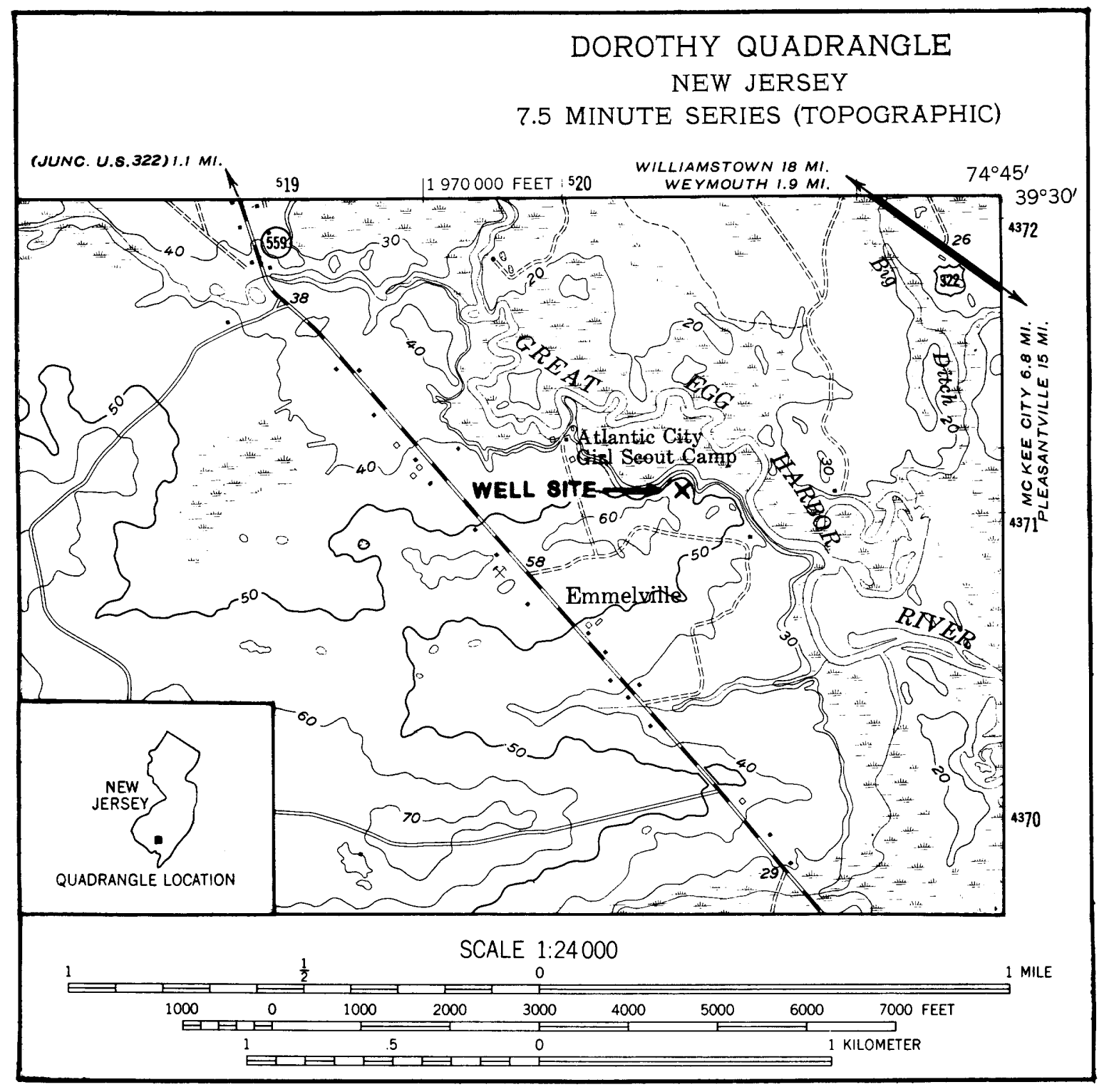

Figure 1. Atlantic City Girl Scout Camp 4 borehole site, Atlantic County, N.J.

The most comprehensive early report on the stratigraphic occurrence of fossil diatoms in New Jersey was made by Woolman $(1895$, p. 160-172), who discussed extensively the diatomaceous clay beds encountered in an artesian well at Wildwood, N.J. He reported, however, on a stratigraphic section considerably downdip and hence stratigraphically thicker than that at the ACGSC-4 site studied for this report. Woolman recognized four distinctive diatomaceous deposits in the Wildwood well. The uppermost of these he termed "Diatom bed no. 1 " and reported as occurring from depths of 29 to 46 feet (9 to $14 \mathrm{~m})$. This bed, which contained a relatively modern marine diatom assemblage, probably of Pleistocene or Holocene age, was noted as being distinct from the older Miocene diatom assemblages. Woolman's "Diatom bed no. 2" came from depths of from 78 to 181 feet ( 24 to 55 $\mathrm{m}$ ) and, from the information given, appears to contain a mixture of marine and nonmarine diatoms. The species list published by Boyer (1895) from these beds was reprinted by Woolman (1895, p. 163-165). Evaluating this diatomaceous deposit by modern standards is difficult, but the deposit's stratigraphic position suggests that it may be of Pleistocene age.

"Diatom bed no. 3" is also termed the "Great 400-Foot Marine Miocene Diatomaceous Bed" by Woolman (1895, p. 165-169), and it is reported to occur in outcrop at Asbury Park and Shiloh, N.J., and in the subsurface at Asbury Park, Barnegat, Beach Haven, Atlantic City, Ocean City, Wildwood, Pleasant Mills, May's Landing, and Port Norris, N.J. The thickness of 


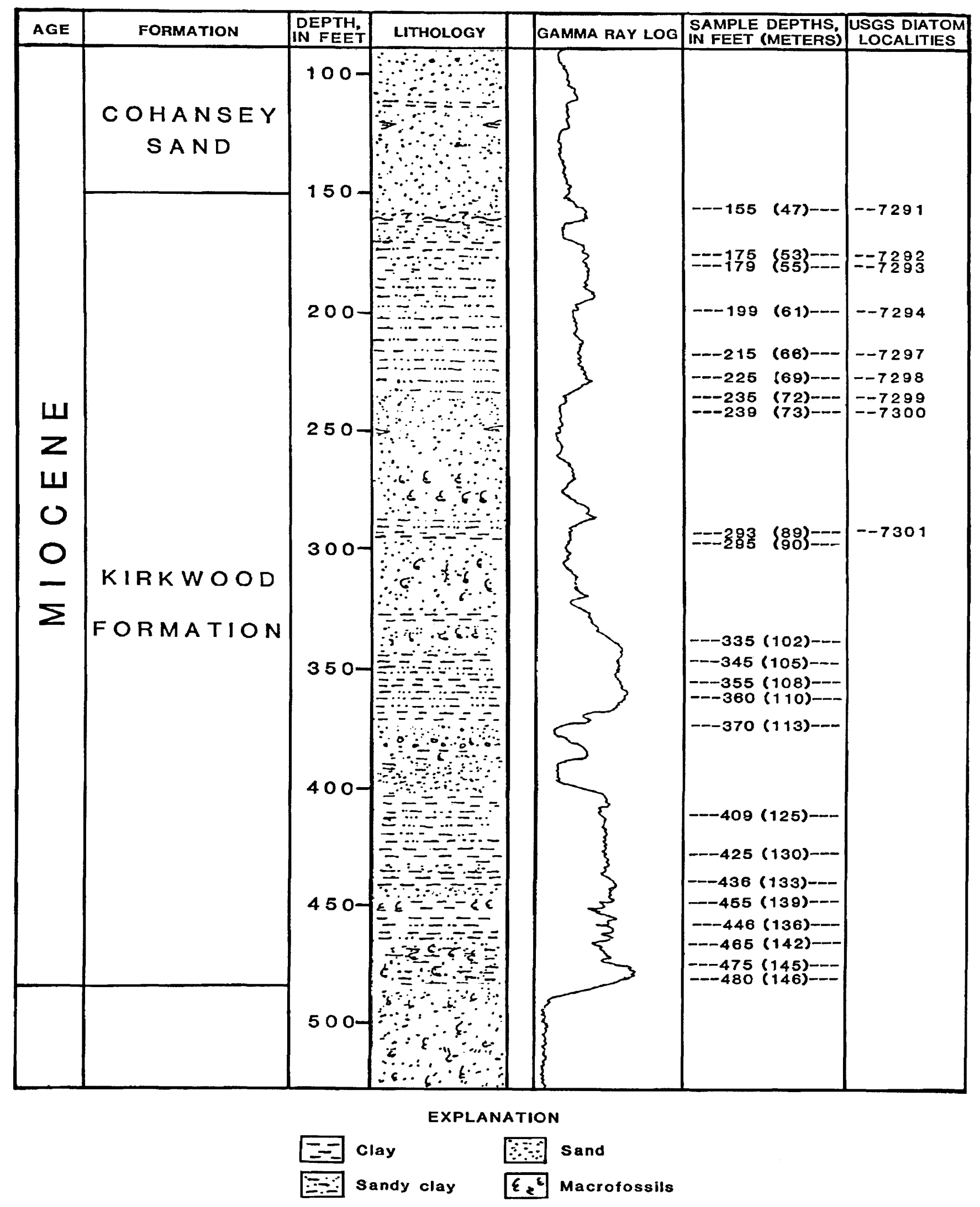

Figure 2. Stratigraphic position and depth of samples studied for diatoms in the Atlantic City Girl Scout Camp 4 borehole, Atlantic County, N.J. 
bed no. 3 is reported as 290 feet $(88 \mathrm{~m})$ at Atlantic City and as 423 feet $(132 \mathrm{~m})$ downdip at Wildwood, N.J. Woolman makes a positive correlation of this bed with the deposits along Chesapeake Bay and Popes Creek, Md., as well as other localities in Delaware, Maryland, and Virginia. Woolman reported that "Diatom bed no. 4" $(1895$, p. 169) occurred as a distinct bed in the Wildwood well from depths of 1,040 to 1,060 feet ( 317 to $323 \mathrm{~m}$ ) and that it is separated from bed no. 3 by a section of nondiatomaceous strata approximately 247 feet $(75 \mathrm{~m})$ in thickness. Woolman (1895, p. 170) stated that the diatom assemblage of bed no. 4 is similar to that of bed no. 3 , but that bed no. 4 is characterized by the occurrence of Actinoptychus heliopelta. Concerning $A$. heliopel$t a$, he stated (p. 172), "This diatom is especially characteristic of the base, and the base only, of the Miocene diatomaceous clay deposits of the Atlantic coastal plain."

Following these pioneer diatom studies by Kain, Schultze, Boyer, and Woolman, little formal biostratigraphic work was conducted on the fossil diatoms of New Jersey. Aside from incidental references to the occurrence of diatom species scattered in the diatom literature, only one significant publication has appeared. Patrick (1944) reported on the Miocene diatoms from a well boring at Brandywine Lighthouse in Delaware Bay. This paper described selected, as well as new, species and, as the author stated (p.1), “. . . no attempt has been made to identify all the species present." The diatoms studied and reported on were recognized to be of Miocene age.

\section{SUMMARY OF INVESTIGATION}

Twenty-three samples were examined for diatoms from the ACGSC-4 borehole core. These ranged in depth from 155 to 480 feet ( 47 to $146 \mathrm{~m}$ ). The depths of individual samples are indicated on figure 2. Those samples not found to contain diatoms are shown only by their depths, whereas those containing diatoms are shown by their depths and the four-digit USGS diatom locality numbers. All of the diatomaceous samples were taken from the Kirkwood Formation. Those samples taken from the upper part of the Kirkwood Formation between depths of 155 and 239 feet $(47$ and $73 \mathrm{~m})$ contained reasonably well preserved diatom assemblages. The interval between 239 and 293 feet (73 and $89 \mathrm{~m}$ ) was not sampled because of the sandy nature of the rocks and poor core recovery. A sample taken from a depth of 293 feet $(89 \mathrm{~m})$ contained a sparse, fragmentary, and weathered diatom assemblage, distinct from those of the overlying strata. Fourteen samples taken from the lower part of the section logged as Kirkwood Formation, between depths of 295 and 480 feet (90 and $146 \mathrm{~m}$ ), do not contain diatoms.

\section{DIATOM BIOSTRATIGRAPHY}

The uppermost diatomaceous interval in the ACGSC-4 borchole at a depth of 155 to 239 feet (47 to $73 \mathrm{~m}$ ) is apparently the equivalent of "Diatom bed no. 3" reported by Woolman (1895, p. 165-199) from an artesian well at Atlantic City, N.J. The samples from this upper interval in ACGSC-4 contain a substantial amount of diatoms and diatom debris showing fair preservation. The assemblages are dominated by the small centric species Paralia sulcata (Ehrenberg) Cleve and contain common large centric diatom species and small pennate diatom species. Most of these forms are shallow-water pelagic or benthic species that suggest deposition in shallow marine waters. Woolman $(1891,1895)$ published a list of 149 diatom species from his Atlantic City well samples. The ACGSC-4 borehole samples probably would yield a similar number of diatom taxa if the samples were studied exhaustively. However, many of these diatom taxa are long ranging (including the abundant Paralia sulcata), from at least Miocene to modern ocean environments, and hence are not useful for biostratigraphic correlation. Others are known to be restricted to fossil deposits, but their precise stratigraphic ranges are not yet well known. I have, therefore, restricted my attention to a relatively few diatom taxa that have proven to be useful as biostratigraphic markers farther south on the Atlantic Coastal Plain-from Maryland (Andrews, 1978) to Georgia (Abbott and Andrews, 1979; Andrews and Abbott, 1985).

The occurrence of these selected marker diatom species in the ACGSC-4 borehole core samples is shown in table 1 . The details of occurrence of each taxon will be presented in the section on systematic paleontology. In general, the marker diatoms correlate these beds well with East Coast Diatom Zone 2 as proposed by Andrews (1978) for the Miocene rocks of the Chesapeake Bay region of Maryland. These diatoms suggest correlation of the upper part of the Kirkwood Formation as exposed in the ACGSC -4 borehole with the upper part of Lithologic Units 3 to 9 of the Calvert Formation in Maryland, these lithologic units being equivalent to the "zones" of Shattuck (1904).

This correlation can be defined a little more precisely perhaps by consideration of the occurrence of the species of Sceptroneis. Sceptroneis grandis and S. hungarica were observed only in the two uppermost samples of the sequence in ACGSC-4, whereas $S$. caduceus was observed in six older samples (loc. nos. 7293-7300). Although this change in species is not absolutely clear cut in Maryland, it apparently occurs within Lithologic Units 6 to 8 of the Calvert Formation. The change in Sceptroneis between samples at 155 and 179 feet $(47$ and $55 \mathrm{~m}$ ) in the ACGSC -4 borehole in the Kirkwood Formation 
Table 1. Stratigraphic occurrence of marker diatoms in the Atlantic City Girl Scout Camp 4 core samples, Atlantic County, N.J.

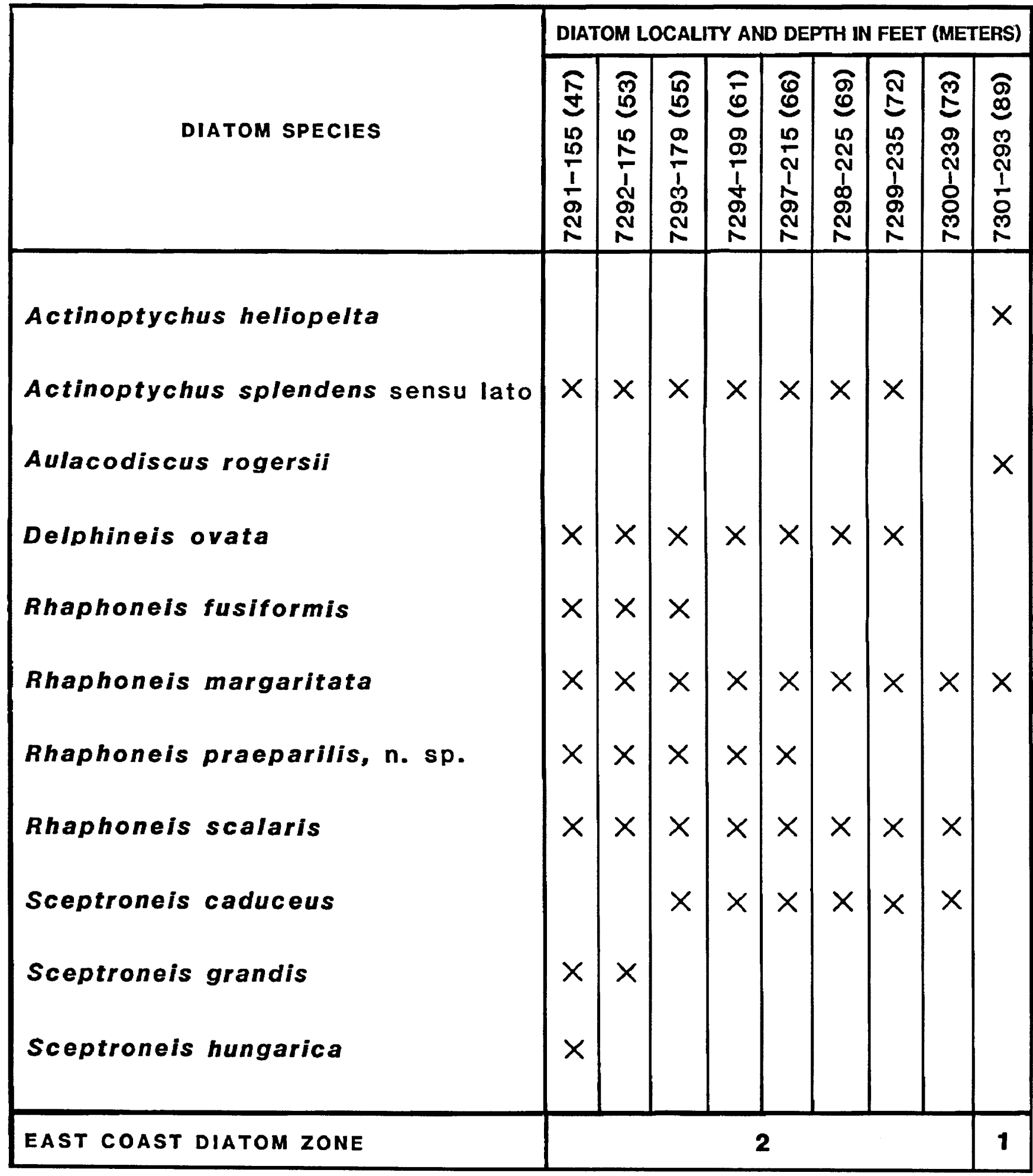

should therefore approximate Lithologic Units 6 to 8 in the Calvert Formation.

The single diatomaceous sample from a depth of 293 feet $(89 \mathrm{~m})$ is separated from the overlying diatomaceous interval by 54 feet $(16 \mathrm{~m})$ of sandy sediments in which core recovery was poor and which were unlikely to contain diatoms. The diatomaceous sample at a depth of 293 feet $(89 \mathrm{~m})$ contains diatom debris of extremely poor preservation in which only the fragments of diatoms most resistant to dissolution were observed. However, four- 
and five-pointed star-shaped hyaline centers of Actinoptychus heliopelta suggest that this bed is substantially older than the upper diatomaceous sequence observed in ACGSC-4. The observed fragments of Actinoptychus heliopelta are definitive for that species, for no other known Miocene diatom has a central hyaline area having four- or fivefold stellate symmetry. Such fragments have been observed also in Maryland in connection with more complete but weathered specimens of $A$. heliopelta. Actinoptychus heliopelta is considered to be a marker diatom for East Coast Diatom Zone 1 of Andrews (1978), and it appears to be separated in Maryland from zone 2 by a substantial period of time. The sample from the 293-foot (89-m) depth appears to correlate with the lower part of Lithologic Unit 3 of the Calvert Formation as exposed along the Patuxent River and elsewhere in Maryland. Woolman (1895, p. 169-170) indicated that a "Diatom bed no. 4," of about 20 feet $(6 \mathrm{~m})$ in thickness containing $A$. heliopelta occurs in an artesian well at Atlantic City, N.J. The extremely degraded diatom fragments at a depth of 293 feet $(89 \mathrm{~m})$ in the core probably represent the extreme updip limit of preserved zone 1 diatoms in the New Jersey Coastal Plain deposits.

Although the above proposed correlations of the New Jersey Miocene strata are reasonably definitive, a few minor anomalies cannot be readily resolved at this time. The two uppermost samples in the ACGSC-4 contained rare specimens whose external outlines resemble Rhaphoneis amphiceros (Ehrenberg) Ehrenberg and Rhaphoneis scutula Andrews, species not known to occur elsewhere in the Atlantic Coastal Plain earlier than in East Coast Diatom Zone 6 of Andrews (1978) of middle Miocene (Serravallian) age. If these specimens are truly conspecific with $R$. amphiceros and $R$. scutula, they may represent sample contamination from unspecified younger strata. Closer examination, however, suggests that these specimens resemble Rhaphoneis parvula Andrews, a small and long-ranging species. These forms may suggest the evolutionary derivation of $R$. amphiceros and $R$. scutula from $R$. parvula. However, they were far too rare in these samples to treat with certainty in this report.

Another interesting feature is the rare to frequent occurrence in the upper five samples of the core of a small lanceolate fragilarioid diatom herein described as Rhaphoneis praeparilis $\mathrm{n}$. $\mathrm{sp}$. Although this diatom is similar to Rhaphoneis parilis from East Coast Diatom Zones 3 to 6 in Maryland, it has no recognized analog there in diatom zone 2. Rhaphoneis praeparilis is defined and distinguished from $R$. parilis in the section on systematic paleontology. This diatom occurs too frequently in the core to be readily dismissed as a contaminant. The seemingly anomalous occurrences of diatoms resembling younger forms may reflect somewhat different environmental conditions in the New Jersey Coastal Plain than were present farther south. The occurrence of cooler Miocene waters in New Jersey is one such possibility. However, no definitive statement can be made until more stratigraphic sections are studied and evaluated.

\section{AGE OF DIATOM ASSEMBLAGES AND MIOCENE STRATA}

The older of the two diatom assemblages represented in the ACGSC-4 borehole core at a depth of 293 feet $(89 \mathrm{~m})$ appears to be of late Burdigalian age (late early Miocene). In Maryland, East Coast Diatom Zone 1 of Andrews (1978) and Atlantic Margin Siliceous Microfossil Zone 1 of Abbott (1978) were reported to contain the marker silicoflagellate Naviculopsis quadrata, as well as the marker diatom Actinoptychus heliopelta. Andrews (unpublished data, 1984) found in several localities in Maryland that the boundary between the Naviculopsis quadrata silicoflagellate zone of Bukry and Foster (1974) and the Naviculopsis ponticula silcoflagellate zone of Bukry (1981b) falls within the Actinoptychus heliopelta diatom zone of Andrews (1978) and Abbott (1978). This boundary between the Naviculopsis quadrata and $N$. ponticula silicoflagellate zones is correlated by Bukry (1981b, p. 434) with that between the Sphenolithus belemnos calcareous nannofossil zone and the overlying Helicosphaera ampliaperta calcareous nannofossil zone; that is, between nannofossil zones CN3 and CN4 (Bukry, 1981a, p. 338). The Neogene time scale of Berggren and others (1985) indicates an absolute age of about $17.1 \mathrm{Ma}$ for this zone boundary. This age falls within the planktic foraminifera zone N7 of Blow (1969) and agrees with the assessment of Abbott (1978, p. 25), who assigned the Actinoptychus heliopelta diatom zone to N6 or N7. Unfortunately, no diagnostic silicoflagellate species was observed in the 293-foot (89-m) poorly preserved sample from the ASGSC-4 borehole, but the evidence cited above suggests a date near $17.1 \mathrm{Ma}$ for this bed, a late Burdigalian age (late early Miocene), and a correlation with planktic foraminifera zone $\mathrm{N} 7$ and with calcareous nannofossil zones NN4 and CN3 to CN4.

The younger of the two diatom assemblages in the core, from 155 to 239 feet ( 47 to $73 \mathrm{~m}$ ) in depth, appears to be Langhian (early middle Miocene) in age. In Maryland, East Coast Diatom Zone 2 of Andrews (1978) and Atlantic Margin Siliceous Microfossil Zone 2 of Abbott (1978), which are approximately equivalent, include the upper part of Lithologic Unit 3 and Units 4 through 9 of the Calvert Formation. Abbott (1978, p. 25) correlates this diatom zone with planktic foraminifera zones N8 to N9 of Blow (1969) and calcareous nannofossil zone NN5 of Martini and Worsley (1970). Following the Neogene time scale of Berggren and others (1985), I estimate that diatom zone 2 began at about $16.0 \mathrm{Ma}$ and ended at about $15.6 \mathrm{Ma}$ and that the upper diatomaceous interval 
in the ACGSC -4 borehole falls within this time constraint. These diatom assemblages are probably of late Langhian age, although diatom zone 2 does extend upward into the base of the Serravallian.

The sandy sediments between depths of 239 and 293 feet (73 and $89 \mathrm{~m}$ ) have no analog in any known Maryland deposits. In Calvert and Anne Arundel Counties, Md., the diatomaceous sediments of diatom zone 2 rest directly on the weathered surface of diatom zone 1 (Andrews, unpublished data). These intercalated sandy deposits in New Jersey must represent sedimentation during some portion of the time between 17.1 and 16.0 Ma.

The lower part of the Kirkwood Formation between 295 and 480 feet ( 90 and $146 \mathrm{~m}$ ) was extensively sampled for diatoms (see fig. 2), but no diatoms or diatom fragments were observed. The relatively thin Lithologic Units 1 and 2, 7 feet $(2.1 \mathrm{~m})$ or less in thickness, assigned by Shattuck (1904) to the Calvert Formation in Maryland may be in some part equivalent to this 185 -foot $(56-\mathrm{m})$ section of the core, but there are no diatoms in this section to help us. However, a probable early Miocene age, based on calcareous nannofossils at a depth of 478.5 feet $(146 \mathrm{~m})$ in the core, was suggested by L.M. Bybell and R.Z. Poore (U.S. Geological Survey Report on Referred Fossils, Jan. 18, 1985). An age of early Miocene (planktic foraminiferal zone N5) was suggested by contained planktic foraminifera for a sample at a depth of 473 feet $(144 \mathrm{~m})$ by R.Z. Poore (U.S. Geological Survey Report on Referred Fossils, April 1985). This age suggests that the base of the Kirkwood Formation, as represented in the core, may be early Burdigalian (early Miocene) in age, approximately $21.8 \mathrm{Ma}$ to $19.0 \mathrm{Ma}$.

\section{PALEOECOLOGY}

The diatom assemblages observed in the ACGSC -4 borehole core are dominated by the small centric marine diatom Paralia sulcata (Ehrenberg) Cleve. This diatom, although not necessarily confined to shallow marine waters, is found most abundantly in marine waters of normal salinity in shallow shelf environments. Modern blooms of this taxon apparently occur in shallow marine waters enriched by nutrient-laden upwelling waters from the deeper parts of the ocean basin. Species of Delphineis living in modern oceans are thought to be indicators of coastal upwelling waters, and, by analogy, Delphineis ovata may be considered such an indicator during its range in early to middle Miocene time. The core samples contain richly varied diatom assemblages, and only a few significant diatom taxa have been studied in detail for this report. I have not personally attempted to identify all of the diatom taxa in these core samples because many are long ranging and are not biostratigraphically useful.
However, C.H. Kain (in Woolman, 1895, p. 167-169) prepared a floral list of diatoms from an artesian well at Atlantic City, N.J., having 149 taxa in 49 genera of diatoms. We cannot be certain that all of these taxa are still considered to be valid, but the ACGSC-4 samples must correlate with at least a part of Woolman's 400 -foot (122-m) "Diatom bed no. 3." The report of 149 taxa from a Miocene diatomaceous unit does not seem unreasonable, considering that samples from many different levels probably were examined exhaustively. Scanning this list by Kain (in Woolman, 1895, p. 168-169), the preponderance of diatom taxa are easily recognized as marine species, and relatively few as nonmarine. The early workers undoubtedly worked with cable-tool well cuttings, with which the opportunities for contamination were considerable. Nor do we know how careful the workers were in their sample preparations. I have not observed any significant nonmarine or brackish water diatom component in the ACGSC -4 borehole core samples; therefore, I consider that the deposits were laid down in a shallow shelf environment, in marine waters of normal to near-normal salinity.

\section{SYSTEMATIC PALEONTOLOGY}

This report deals specifically with the diatom taxa in the ACGSC-4 borehole core known to have biostratigraphic value as markers. The genera and species of diatoms studied in this report are arranged in alphabetical order to facilitate use by the reader. A systematic arrangement has not been made because this paper is primarily of interest to the diatom biostratigrapher, to whom a suprageneric classification is of little consequence.

The format of discussion follows that used by the writer in earlier reports on fossil marine diatom assemblages of the Eastern United States. The first citation in each synonymy is to the basionym of the taxon. The second citation is to the name adopted for use in this report, with appropriate references in chronological order. Subsequent citations include synonyms, misidentifications, and other errata. These synonymies emphasize the reported fossil occurrences in the Eastern United States, and they are not designed to be exhaustive. Information is given on the known geologic ranges of all taxa herein studied because such information is critical to the continuing development of diatom biostratigraphy.

\section{Genus ACTINOPTYCHUS Ehrenberg, 1841}

Actinoptychus heliopelta Grunow

Plate 1, figures 1, 2

Actinoptychus heliopelta Grunow, in Van Heurck, 1883, pl. 123, fig. 3; Schmidt and others, 1890, pl. 153, fig. 22; Boyer, 
1904 , p. 499, pl. 134, fig. 3; Lohman, 1948, p. 169, p1. 9, fig. 3; Andrews, 1978, p. 382, pl. 1, figs. 7, 8, pl. 6, fig. 2; Andrews, 1979, p. 79-98, pls. 1-5.

Heliopelta spp. Ehrenberg, 1845, p. 268; Ralfs, in Pritchard, 1861 , p. 841.

Discussion. - Fragments of Actinoptychus heliopelta were observed only in the sample examined from USGS diatom locality 7301, at a depth of 293 feet $(89 \mathrm{~m})$ in the ACGSC -4 borehole. These fragments consist of the hyaline centers of valves having attached hyaline rays that extend into alternate sectors of the valve. These star-shaped fragments show both a fourfold (see pl. 1, fig. 1) and a fivefold (see pl. 1, fig. 2) symmetry, which can be identified only with Actinoptychus heliopelta. Similar fragments have been observed in Miocene rocks of Maryland in connection with well-preserved specimens of $A$. heliopelta. The solid hyaline central part of the valve is apparently the part most resistant to dissolution.

Known geologic range. - From East Coast Diatom Zone 1 (Actinoptychus heliopelta partial range zone of Andrews, 1978, p. 377-378) and upper part of the Naviculopsis quadrata silicoflagellate zone of Bukry and Foster (1974) into the overlying Naviculopsis ponticula silicoflagellate zone of Bukry (1981b). This silicoflagellate zone boundary occurs at approximately $17.1 \mathrm{Ma}$ in the Burdigalian Stage of early Miocene age. The 293-foot (89-m) bed in the ACGSC -4 borehole appears to be the age equivalent of the older part of Lithologic Unit 3 of the Calvert Formation as exposed near Dunkirk and elsewhere in Maryland. It is substantially older than the other diatomaceous beds found in the ACGSC-4 borehole.

Actinoptychus splendens (Shadbolt) Ralfs sensu lato

Plate 1, figures $3-6$

Actinosphaenia splendens Shadbolt, 1854, p. 16.

Actinoptychus splendens (Shadbolt) Ralfs, in Pritchard, 1861, p. 840; Hustedt, 1929, p. 478-480; Lohman, 1948, p. 170; Hendey, 1964, p. 95 , pl. 22 , fig. 1.

Actinoptychus splendens var. nicobarica Grunow, in Van Heurck, 1883, pl. 120, fig. 4.

Actinoptychus nicobaricus (Grunow) Andrews, 1978, p. 383, pl. 2 , fig. 3 .

Actinoptychus australis (Grunow) Andrews, 1978, p. 382, pl. 1, fig. 5 .

Discussion. - The diatoms here considered as Actinoptychus splendens (Shadbolt) Ralfs occur rarely throughout the section of East Coast Diatom Zone 2 in the ACGSC-4 borehole. In Andrews (1978) I identified $A$. australis and $A$. nicobaricus as occurring in East Coast Diatom Zone 2 in Maryland. The identification of these taxa in Miocene rocks of this age is no longer tenable. The differentiation of $A$. australis and $A$. nicobaricus from the better known and still living $A$. splendens appears to be based mainly on a single morphologic feature, a very thin median hyaline ray bisecting, from central area to margin, each externally raised sector. In $A$. splendens, this ray is continuous from the hyaline central area to the labiate process near the margin of the valve. In $A$. nicobaricus, the ray extends outward from the center and inward from the labiate process, but it is not continuous. In $A$. australis, the ray extends outward from the center only part way toward the labiate process. In specimens from ACGSC -4 , however, I have seen all three of the above ray types on different sectors of the same valve. I have also observed valves, otherwise morphologically indistinguishable, having no discernible hyaline rays on any sector. Hence, these forms must represent a variable population of a single species, rather than three separate species. I therefore propose to assign the forms of Actinoptychus in East Coast Diatom Zone 2 having more than six sectors to $A$. splendens, recognizing that they may well be precursors to the more distinct modern form of the species.

Actinoptychus nicobaricus has thus been placed in synonymy, as has $A$. australis sensu Andrews (1978). I prefer to retain the name $A$. australis for a similarappearing diatom common in the Eastover Formation of Virginia and of late Miocene age. This diatom shows the consistent occurrence of a thin hyaline ray extending from the hyaline center to about half radius on each externally raised sector of the valve. It stands in contrast to the inconsistent occurrence of the hyaline ray in specimens from ACGSC -4 and the hyaline ray extending from center to margin in the modern species.

Known geologic range. - Forms of this variable species have been observed in East Coast Diatom Zone 2 of Andrews (1978) in Maryland from the upper part of Lithologic Unit 3 to Lithologic Unit 8 of the Calvert Formation. In this study, it has been observed rarely in the ACGSC -4 borehole from depths of 155 to 235 feet (47 to $72 \mathrm{~m}$ ).

\section{Genus AULACODISCUS Ehrenberg, 1844}

Aulacodiscus rogersii (Bailey) Schmidt

Plate 1, figure 7

Podiscus rogersii Bailey, 1844, p. 137, pl. 3, figs. 1, 2.

Aulacodiscus rogersii (Bailey) Schmidt, 1875, pl. 107, fig. 3; Rattray, 1888 , p. 372 ; Boyer, 1904, p. 497-498, pl. 134 , fig. 5 .

Description. - Valve round, heavily silicified, nearly flat from center to about half the radius, then smoothly curved to the margin. Diameter of specimen observed, $110 \mu \mathrm{m}$. Valve surface covered with a radiating network of fine areolae, about six in $10 \mu \mathrm{m}$, overlain by a coarser, heavily siliceous reticulating network on the exterior. 
Three to seven ocelluslike structures have been reported on the shoulder of the valve.

Discussion.-Fragments of Aulacodiscus rogersii were found commonly in the sample examined from USGS diatom locality 7301, at a depth of 293 feet $(89 \mathrm{~m})$ in the ACGSC -4 borehole. Numerous fragments of this heavily silicified diatom have been preserved, whereas most of the other diatoms in this bed have been destroyed by dissolution. The fragments of Aulacodiscus rogersii resemble specimens assigned to $A$. argus (Ehrenberg) Schmidt by Lohman (1948, p. 171), Andrews (1980, p. 24-25), and Andrews and Abbott (1985, p. 71-72, pl. 7, fig. 1) from younger Miocene deposits in Maryland and Virginia. However, the specimens assigned to Aulacodiscus rogersii in this study show the distinctively flattened valve center that characterizes $A$. rogersii, whereas the younger forms previously assigned to $A$. argus appear to have a more nearly rounded valve center. Whether those specimens identified as "Aulacodiscus argus" from the younger Miocene strata are truly conspecific with the $A$. argus living in present-day marine waters remains to be determined.

Known geologic range. - Reported by Boyer (1904, p. 498) from localities now known to be in East Coast Diatom Zone 1 of Andrews (1978) or in the older part of Lithologic Unit 3 of the Calvert Formation in Maryland. Boyer (1904) also reported this species from localities probably as young as Lithologic Unit 10 of the Calvert Formation in Maryland. However, I have not observed distinctively flattened specimens attributable to Aulacodiscus rogersii in the younger beds of the Calvert Formation, and Boyer may have confused the dome-shaped species, which has been called $A$. argus with the flattened species $A$. rogersii. Aulacodiscus rogersii may be a marker for East Coast Diatom Zone 1 or for the older part of Lithologic Unit 3 of the Calvert Formation and of the late Burdigalian Stage in Maryland.

\section{Genus DELPHINEIS Andrews, 1977}

Delphineis ovata Andrews

Plate 1, figures 8-14; plate 3, figure 11

Delphineis ovata Andrews, 1977, p. 252-253, pl. 1, figs. 12-15, pl. 2, figs. 25, 26, pl. 4, figs. 33, 34; Andrews, 1978, p. 392, 394, pl. 5, figs. 12-14; pl. 8, figs. 5, 6 .

Description.-Valve elliptical to linear-elliptical, having curved lateral margins terminating in bluntly rounded apices. Length of observed specimens, 30 to 96 $\mu \mathrm{m}$; width about 8 to $10 \mu \mathrm{m}$. Transverse rows of areolae about seven in $10 \mu \mathrm{m}$, having areolae in the bottom of shallow external grooves. Three areolae on each side of hyaline axial area at the center of the valve, reducing to two on each side near the apices. Transverse rows of areolae parallel at center of valve, becoming slightly radiate near the apices. Short, fine rows of areolae radiate around the apices of the valve. Hyaline axial area narrow, about $1 \mu \mathrm{m}$ in width, and pairs of transapical rows of areolae are well aligned across the axial area. The apical fine structures-two minute pores and single labiate processes on each end of the valve (pl. 3, fig. 11)-were preserved in a few specimens studied for this report.

Discussion. - This species was observed rarely to frequently in samples from 155 to 235 feet ( 47 to $72 \mathrm{~m}$ ) in the ACGSC-4 borehole. Delphineis ovata most nearly resembles the younger species Delphineis penelliptica, but it lacks the distinct taper toward the apices that is characteristic of the latter species.

Known geologic range.-Reported by Andrews (1978, p. 394) to range from the younger portion of Lithologic Unit 3 to the top of Lithologic Unit 9 of the Calvert Formation in Maryland. Hence, restricted to East Coast Diatom Zone 2 of the Calvert Formation of Langhian age (early middle Miocene).

\section{Genus RHAPHONEIS Ehrenberg, 1844}

Rhaphoneis fusiformis Andrews

Plate 2, figures 1-4

Rhaphoneis fusiformis Andrews, 1978, p. 386, pl. 3, figs. 14-16.

Description. - Valve lanceolate with protracted apices, which are narrowly rounded to bluntly pointed. Length of observed specimens 40 to $56 \mu \mathrm{m}$; width about $10 \mu \mathrm{m}$. Ends of valve somewhat asymmetrical and often slightly bent in relation to the longitudinal axis. About five or six transverse rows of relatively large areolae in 10 $\mu \mathrm{m}$. Hyaline axial area narrow to narrowly lanceolate, and transverse rows of pores not aligned across it. Apical fine structures consist of a pseudocellus of fine pores and a single labiate process.

Discussion. - Rhaphoneis fusiformis occurs rarely in samples from 155 to 179 feet ( 47 to $55 \mathrm{~m}$ ) in depth in the core.

Known geologic range.-Reported by Andrews (1978, p. 386) from East Coast Diatom Zones 2 and 3 and from the upper part of Lithologic Unit 3 to Unit 11 in the Calvert Formation of the Chesapeake Bay region of Maryland. Langhian in age (early middle Miocene).

\section{Rhaphoneis margaritata Andrews}

Plate 2, figures 5-12; plate 3, figure 10

Rhaphoneis margaritata Andrews, 1978, p. 388, pl. 4, figs. 5-9, pl. 7, fig. 1.

Description. - Valve varies from shorter subrhomboidal specimens having somewhat produced apices to 
longer lanceolate specimens having protracted attenuate apices. Ends narrowly rounded. Length of observed specimens 36 to $168 \mu \mathrm{m}$; width about 16 to $28 \mu \mathrm{m}$. Three to four transverse rows of areolae in $10 \mu \mathrm{m}$, parallel in larger specimens and slightly radiate in smaller specimens. Areolae show a secondary alignment in nearly straight longitudinal rows. Hyaline axial area narrow in the center of the valve and virtually indiscernible near the apices. Transapical rows of areolae not aligned across the axial area. Apical pseudocellus composed of fine pores radiating toward the end of the valve, and a single labiate process occurs in each end of the valve (pl. 3, fig. 10).

Discussion. - This robust and distinctive species of Rhaphoneis is rare to frequent in samples from 155 to 239 feet $(47$ to $73 \mathrm{~m})$ in the core. Fragments were observed in the substantially older 293 -foot (89-m) sample; this occurrence extends the range of the species downward into at least a part of East Coast Diatom Zone 1.

Known geologic range.-Reported by Andrews (1978, p. 388) from East Coast Diatom Zone 2 in the Chesapeake Bay region of Maryland. Found there in Lithologic Units 3 to 8 of the Calvert Formation; hence, Langhian in age (early middle Miocene).

Rhaphoneis praeparilis Andrews, n. sp.

Plate 2, figures 13-19; plate 3, figure 12

Description. - Valve lanceolate, tapering to protracted, narrowly rounded apices. Length of observed specimens, 32 to $50 \mu \mathrm{m}$; width 8 to $11 \mu \mathrm{m}$, eight to eight and a half transverse rows of areolae in $10 \mu \mathrm{m}$, mostly parallel but slightly radiate in some specimens. Areolae show a secondary alignment in nearly straight longitudinal rows. Transverse rows of areolae are well aligned across the narrow but distinct hyaline axial area, having four or five areolae in each row, on either side of the axial area near the center of the valve. Apical pseudocellus composed of fine pores without discernible arrangement. A single labiate process is located between the pseudocellus and the main part of the valve in both ends of the valve (pl. 3, fig. 12).

Discussion. - The species bears a superficial resemblance to Rhaphoneis parilis Hanna, but it shows some distinctive differences in detailed morphology that seem to be consistent. The valve of $R$. praeparilis is a little more broadly lanceolate than that of $R$. parilis. The narrow hyaline axial area of $R$. praeparilis is similar to that of $R$. parilis, rather than so narrow as to be indistinguishable as in $R$. lancettula. The transverse rows of areolae in $R$. praeparilis contain four or five areolae on either side of the axial area in the center of the valve, whereas $R$. parilis shows only three areolae in its transverse rows. Occurs rarely to frequently in samples from 155 to 215 feet $(47$ to $66 \mathrm{~m}$ ) in the core.
Known geologic range.-This form has not been described previously or reported from Miocene deposits in the Eastern United States. Hence, it may be restricted to East Coast Diatom Zone 2 of Andrews (1978) but probably restricted to the northern part of the Atlantic Coastal Plain. Rhaphoneis praeparilis may be ancestral to R. parilis Hanna, reported by Andrews (1978) from East Coast Diatom Zones 3 to 6 and more widely distributed in the coastal plain deposits of the Eastern United States.

Holotype. - USGS diatom catalog no. 4735-7 (pl. 2, fig. 19), length $50 \mu \mathrm{m}$. From USGS diatom locality 7293, ACGSC-4 borehole core, depth 179 feet $(55 \mathrm{~m})$, Atlantic County, N.J.

\section{Rhaphoneis scalaris Ehrenberg}

Plate 2, figures 20-23; plate 3, figure 9

Rhaphoneis scalaris Ehrenberg, 1845, p. 271; Grunow, in Van Heurck, 1881, pl. 36, fig. 32; Lohman, 1948, p. 183, pl. 11, fig. 3; Andrews, 1975, p. 216, pl. 3, figs. 49, 50, pl. 5, figs. 64, 65; Andrews, 1978, p. 389, pl. 4, figs. 10, 11, pl. 7, fig. 6.

Description. - Valve narrowly lanceolate, having protracted apices. Length of observed specimens about 83 to $104 \mu \mathrm{m}$, width 13 to $15 \mu \mathrm{m}$, but many specimens are incompletely preserved in these samples. Four transverse rows of areolae in $10 \mu \mathrm{m}$, composed of large, irregularly sized areolae. Transverse rows of areolae separated by strong siliceous transverse ribs, but the areolae themselves are separated by thinner longitudinal septa located near the outer surface of the valve. Hyaline axial area narrow but distinct, tapering slightly toward the apices. The transverse rows of areolae are not aligned across axial area. A small apical pseudocellus of fine pores occurs on each end of the valve but is usually poorly preserved. Apical processes not known.

Discussion. - This distinctive species is characterized by its delicate lanceolate shape and its peculiar elongate and irregular areolae. It occurs as fragments and rare whole specimens in samples from 155 to 239 feet $(47$ to $73 \mathrm{~m})$ in the core.

Known geologic range.-Reported by Andrews (1978, p. 389) from East Coast Diatom Zone 2 in the Chesapeake Bay region of Maryland. Found there in Lithologic Units 3 to 8 of the Calvert Formation; hence, Langhian in age (early middle Miocene).

\section{Genus SCEPTRONEIS Ehrenberg, 1844}

Sceptroneis caduceus Ehrenberg

Plate 3, figures $1-5$

Sceptroneis caduceus Ehrenberg, 1845, p. 271; Ehrenberg, 1854 , pl. 33, pt. 17, fig. 15; Van Heurck, 1881, pl. 37, fig. 
5; Boyer, 1904, p. 489, pl. 135, fig. 12; Hustedt, 1931, pl. 130, fig. 651; Lohman, 1948, p. 183-184, pl. 11, fig. 7; Andrews, 1978 , p. 396-397, pl. 5, figs. 18-20, pl. 8, figs. 9, 10 .

Description. - Valve slender, elongate, clavate, having a larger broadly rounded capitate head-pole and a distinctly smaller sharply rounded foot-pole. Many specimens show a slight to moderate central swelling of the valve. Some specimens slightly curved longitudinally, and others somewhat twisted around the longitudinal axis. The species is highly variable in length and shape. Whole specimens are extremely rare in the samples studied for this report. Andrews (1978) reported a length range of 57 to $>269 \mu \mathrm{m}$. Valves generally narrow, about 8 to $10 \mu \mathrm{m}$ in width. Transverse rows of areolae about five in $10 \mu \mathrm{m}$, short and parallel, not aligned across axial area. Hyaline axial area narrow, but distinct. Both ends show a single centrally located labiate process forming the focal point of fine pores of the pseudocellus radiating to the tip of the valve.

Discussion.-Sceptroneis caduceus is readily distinguishable from $S$. grandis and $S$. hungarica by its much more delicately silicified valves and by the strikingly expanded head-pole in which the pseudocellus is readily resolved by the light microscope. Fragments of $S$. caduceus are frequent to common in the core from depths of 179 to 239 feet (55 to $73 \mathrm{~m}$ ).

Known geologic range.-Reported by Andrews (1978) from rocks of late Burdigalian age (late early Miocene) to Langhian age (early middle Miocene). From East Coast Diatom Zones 1 and 2 of Andrews (1978), but apparently ranging only as high as Lithologic Unit 8 of the Calvert Formation in the Chesapeake Bay region and hence extinct below the top of Diatom Zone 2.

\section{Sceptroneis grandis Abbott}

Plate 3, figures 6,7

Sceptroneis grandis Abbott, in Abbott and Ernissee, 1983, p. 302-303, pl. 11, fig. 7, pl. 12, fig. 1.

Sceptroneis caduceus Hanna, 1932 (non Ehrenberg, 1845), p. 216-217, pl. 16, figs. 5-7.

Description. - Valve heavily silicified, clavate, lanceolate, having a bluntly rounded head-pole and a more narrowly rounded foot-pole. Length of observed specimens, 114 to $120 \mu \mathrm{m}$, but range in length is much greater than this. Width about $15 \mu \mathrm{m}$. About three and a half transverse rows of areolae in $10 \mu \mathrm{m}$, short and parallel, having large, well-defined areolae. The transverse rows of areolae are not aligned across the axial area. Hyaline axial area very narrow, in some specimens distinct, but in others distinguishable only by the misalignment of the areolae on either side. Both ends show a pseudocellus composed of fine pores radiating toward the tip of the valve. Presumably the focal point of the pores of the pseudocellus is a single labiate process, but this structure is not readily discerned under the light microscope.

Discussion. -Sceptroneis grandis is distinct from $S$. caduceus because of its heavier silicification, more massive construction, and coarser areolation. It occurs rarely in the core from depths of 155 and 175 feet (47 and 53 $\mathrm{m})$, the two uppermost diatomaceous samples studied for this report.

Known geologic range. - Reported by Abbott, in Abbott and Ernissee (1983) from planktic foraminiferal zones N8 to N9 in the Pungo River Formation of North Carolina; hence, Langhian (early middle Miocene) in age.

Sceptroneis hungarica (Pantocsek) Andrews

Plate 3, figure 8

Rhaphoneis hungarica Pantocsek, 1886, pt. 1, p. 34, pl. 3, fig. 30, pl. 25, fig. 224.

Sceptroneis hungarica (Pantocsek) Andrews, 1978, p. 398, 400, pl. 5 , figs. $21,22$.

Description. - Valve broadly lanceolate, having only slight longitudinal asymmetry, and ends slightly produced. Head-pole bluntly rounded, and foot-pole slightly more sharply rounded. Length of observed specimen about $48 \mu \mathrm{m}$, and width about $15 \mu \mathrm{m}$, somewhat smaller than reported by Andrews (1978) for this species. Three to three and a half transverse rows of areolae in 10 $\mu \mathrm{m}$, composed of few large, round areolae. Axial area very narrow, only the dividing line between nonaligned rows of areolae on either side of the valve. Apical fine structures not observed.

Discussion. - The relatively short valve of $S$. hungarica, and its blunt and noncapitate apices, distinguishes this species morphologically from $S$. grandis. The species was rare in the uppermost diatomaceous sample examined from the core, at 155 feet $(47 \mathrm{~m})$.

Known geologic range.-Reported by Andrews (1978) in East Coast Diatom Zone 2 from about the middle of undifferentiated Lithologic Units 4 to 8 and in Unit 9 of the Calvert Formation in the Chesapeake Bay region. Langhian (early middle Miocene) in age.

\section{REFERENCES CITED}

Abbott, W.H., 1978, Correlation and zonation of Miocene strata along the Atlantic margin of North America using diatoms and silicoflagellates: Marine Micropaleontology, v. 3, p. $15-34$, pls. $1,2$.

Abbott, W.H., and Andrews, G.W., 1979, Middle Miocene marine diatoms from the Hawthorn Formation within the Ridgeland Trough, South Carolina and Georgia: Micropaleontology, v. 25, no. 3, p. 225-271, pls. 1-8.

Abbott, W.H., and Ernissee, J.J., 1983, Biostratigraphy and paleoecology of a diatomaceous clay unit in the Miocene 
Pungo River Formation of Beaufort County, North Carolina: Smithsonian Contributions to Paleobiology, no. 53, p. 287-353, pls. 1-26.

Andrews, G.W., 1975, Taxonomy and stratigraphic occurrence of the marine diatom genus Rhaphoneis: Nova Hedwigia, no. 53, p. 193-222, pls. 1-5.

- - 1977, Morphology and stratigraphic significance of Delphineis, a new marine diatom genus: Nova Hedwigia, no. 54 , p. 243-260, pls. $1-8$.

_ -1978 , Marine diatom sequence in Miocene strata of the Chesapeake Bay region, Maryland: Micropaleontology, v. 24 , no. 4 , p. $371-408$, pls. $1-8$.

- - - 1979, Morphologic variations in the Miocene diatom Actinoptychus heliopelta Grunow: Nova Hedwigia, no. 64, p. $79-98$, pls. $1-5$.

- -1980 , Neogene diatoms from Petersburg, Virginia: Micropaleontology, v. 26, no. 1, p. 17-48, pls. 1-6.

Andrews, G.W., and Abbott, W.H., 1985, Miocene diatoms from the Hawthorn Formation, Thomas County, Georgia: Bulletins of American Paleontology, v. 87, no. 321, p. 53-109, pls. 6-13.

Bailey, J.W., 1844, Account of some new infusorial forms discovered in the fossil Infusoria from Petersburg, Virginia, and Piscataway, Maryland: American Journal of Science, v. 46, p. 131-141, pl. 3.

Berggren, W.A., Kent, D.V., Flynn, J.J., and Van Couvering, J.A., 1985, Cenozoic geochronology: Geological Society of America Bulletin, v. 96, no. 11, p. 1407-1427.

Blow, W.H., 1969, Late Middle Eocene to Recent planktonic foraminiferal biostratigraphy, biochronology and paleoclimatology: First International Conference on Planktonic Microfossils, Geneva, Switzerland, 1967, Proceedings, v. 1, p. $199-422$, pls. 1-54. text figs. 1-43.

Boyer, C.S., 1895, A diatomaceous deposit from an artesian well at Wildwood, N.J.: Bulletin of the Torrey Botanical Club, v. 22, no. 6, p. 260-266.

- - 1904, Thallophyta-Diatomacea, in Systematic paleontology of the Miocene deposits of Maryland: Maryland Geological Survey, Miocene, p. 487-507, pls. 134, 135.

Bukry, D., 1981a, Cenozoic coccoliths from the Deep Sea Drilling Project: Society of Economic Paleontologists and Mineralogists, Special Publication 32, p. 335-353.

_ $-1981 \mathrm{~b}$, Synthesis of silicoflagellate stratigraphy for Maestrichtian to Quaternary marine sediment: Society of Economic Paleontologists and Mineralogists, Special Publication 32, p. 433-444.

Bukry, D., and Foster, J.H., 1974, Silicoflagellate zonation of Upper Cretaceous to lower Miocene deep-sea sediment: U.S. Geological Survey Journal of Research, v. 2, no. 3, p. 303-310.

Cook, G.H., 1868, Geology of New Jersey: New Jersey Geological Survey publication, $900 \mathrm{p}$.

Ehrenberg, C.G., 1845, Untersuchungen über die kleinsten Lebens formen im Quellenlande des Euphrats und Araxes, so wie über eine an neuen Formen sehr reiche marine Tripelbildung von den Bermuda-Inseln: Königlichen preussischen Akademie der Wissenschaften zu Berlin, Bericht 1844, p. 253-275.
- - 1854, Mikrogeologie: Leipzig, L. Voss, p. 1-374, pls. 1-41.

Goldstein, F.R., 1974, Paleoenvironmental analyses of the Kirkwood Formation: Rutgers University, unpublished Ph.D. dissertation, 70 p.

Hanna, G.D., 1932, The diatoms of Sharktooth Hill, Kern County, California: California Academy of Sciences, Proceedings, ser. 4 , v. 20 , no. 6 , p. 161-263, pls. 2-18.

Hendey, N.I., 1964, An introductory account of the smaller algae of British coastal waters, pt. V, Bacillariophyceae (Diatoms): London, Ministry of Agriculture, Fisheries, and Food, Fishery Investigations Series 4, p. 1-317, pls. $1-45$.

Hustedt, Friedrich, 1927-1966, Die Kieselalgen Deutschlands, Österreichs und der Schweiz: Band 7 of Rabenhorst, G.L., Kryptogamenflora***: Leipzig, Akademische Verlagsgesellschaft, pt. 1, p. 1-920, figs. 1-542, 1927-1930; pt. 2, p. $1-845$, figs. $543-1179$, 1931-1959; pt. 3, p. 1-816, figs. 1180-1788, 1962-1966.

Isphording, W.C., 1970, Petrology, stratigraphy and re-definition of the Kirkwood Formation (Miocene) of New Jersey: Journal of Sedimentary Petrology, v. 40, no. 3, p. 986-997.

Kain, C.H., and Schultze, E.A., 1889, On a fossil marine diatomaceous deposit from Atlantic City, N.J.: Bulletin of the Torrey Botanical Club, v. 6, p. 71-76, 207-210, pls. 89, 92, 93.

Knapp, G.N., 1904, Underground waters of New Jersey; wells drilled in 1903: New Jersey Geological Survey, Annual Report for 1903, part 4, p. 73-93.

Lohman, K.E., 1948, Middle Miocene diatoms from the Hammond well, in Cretaceous and Tertiary subsurface geology: Maryland Department of Geology, Mines and Water Resources, Bulletin 2, p. 151-187, 331-333, pls. 5-11.

Martini, E., and Worsley, T., 1970, Standard Neogene calcareous nannoplankton zonation: Nature, v. 225, p. 289-290.

Pantocsek, Josef, 1886, Beiträge zur Kenntniss der fossilen Bacillarien Ungarns: Nagy-Tapolcsány, Julius Platzko, pt. 1, p. 1-75, pls. 1-30.

Patrick, Ruth, 1944, Well-boring at Brandywine lighthouse in Delaware Bay, pt. 2, Miocene diatoms: Academy of Natural Sciences of Philadelphia, Notulae Naturae, no. 133, 13 p., 1 pl.

Pritchard, Andrew, 1861, A history of Infusoria, 4th ed.; London, Whittaker and Co., p. 1-968, pls. 1-40.

Rattray, John, 1888, A revision of the genus Aulacodiscus Ehrb.: Royal Microscopical Society Journal 1888, p. 337-382, pls. 5-7.

Richards, H.G., and Harbison, Anne, 1942, Miocene invertebrate fauna of New Jersey: Academy of Natural Sciences of Philadelphia, v. 44, p. 167-250, pls. 7-22.

Schmidt, Adolf, and others, 1874-1959, Atlas der Diatomaceenkunde: Leipzig, O.R. Reisland, pls. 1-480.

Shadbolt, George, 1854, A short description of some new forms of Diatomaceae from Port Natal: Transactions of the Microscopical Society of London, new series, v. 2, pt. 1, p. 13-18, pl. 1.

Shattuck, G.B., 1904, The Miocene deposits of Maryland: Geological and paleontological relations, with a review of earlier investigations: Maryland Geological Survey, Miocene, p. 33-137. 
Spangler, W.B., and Peterson, J.J., 1950, Geology of Atlantic Coastal Plain in New Jersey, Delaware, Maryland, and Virginia: American Association of Petroleum Geologists Bulletin, v. 34, no. 1, p. 1-99.

U.S. Geological Survey, 1972, Dorothy quadrangle, New Jersey: U.S. Geological Survey $71 / 2$-minute topographic map, lat $39^{\circ} 22.5^{\prime} \mathrm{N}$, long $74^{\circ} 45^{\prime} \mathrm{W}$, scale $1: 24,000$.

Van Heurck, Henri, 1880-1885, Synopsis des diatomées de Belgique: Anvers, p. 1-235, pls. 1-132, A-C.
Woolman, Lewis, 1891, Geology of artesian wells at Atlantic City, N.J.: Academy of Natural Sciences of Philadelphia, Proceedings, 1890 , v. 42, p. 132-144.

- - 1892, Review of artesian-well horizons in southern New Jersey: New Jersey Geological Survey, Annual Report of the State Geologist for 1891, p. 223-232.

---1895 , Report on artesian wells in southern New Jersey: New Jersey Geological Survey, Annual Report of the State Geologist for 1894, pt. 2, p. 151-304. 


\section{PLATES 1-3}

Contact photographs of the plates in this report are available, at cost, from the U.S. Geological Survey Library, Federal Center, Denver, CO 80225. 


\section{PLATE 1}

Figure 1, 2. Actinoptychus heliopelta Grunow (p. 8).

1. USGS diatom cat. no. 4743-3, $\times 1,000$, eroded hyaline central area from eight-sectored specimen. From USGS diatom locality 7301.

2. USGS diatom cat. no. 4743-2, $\times 1,000$, eroded hyaline central area from ten-sectored specimen. From USGS diatom locality 7301.

3-6. Actinoptychus splendens (Shadbolt) Ralfs sensu lato (p. 9).

3. USGS diatom cat. no. 4736-5, $\times 500$, diameter $126 \mu \mathrm{m}$. Thin hyaline rays continuous from center to margin in some sectors, discontinuous in others. From USGS diatom locality 7294 .

4. USGS diatom cat. no. $4735-11, \times 500$, diameter $91 \mu \mathrm{m}$. From USGS diatom locality 7293.

5. USGS diatom cat. no. $4735-8, \times 500$, diameter $73 \mu \mathrm{m}$. Thin hyaline rays extend part way from central area to margin. From USGS diatom locality 7293.

6. Scanning electron microscope photograph, $\times 1,100$, diameter of fragment $84 \mu \mathrm{m}$, inside view, thin hyaline rays extend part way from central area to margin. From USGS diatom locality 7297.

7. Aulacodiscus rogersii (Bailey) Schmidt (p. 9). USGS diatom cat. no. 4743-4, $\times 500$, diameter about $120 \mu \mathrm{m}$. Oblique view of large fragment. From USGS diatom locality 7301 .

8-14. Delphineis ovata Andrews (p. 10).

8. USGS diatom cat. no. $4733-8, \times 1,000$, length $32 \mu \mathrm{m}$. From USGS diatom locality 7291 .

9. USGS diatom cat. no. $4736-7, \times 1,000$, length $30 \mu \mathrm{m}$. From USGS diatom locality 7294 .

10. USGS diatom cat. no. $4735-9, \times 1,000$, length $35 \mu \mathrm{m}$. From USGS diatom locality 7293.

11. USGS diatom cat. no. $4739-1, \times 1,000$, length $76 \mu \mathrm{m}$. From USGS diatom locality 7297.

12. Scanning electron microscope photograph, $\times 1,500$, length about $69 \mu \mathrm{m}$. From USGS diatom locality 7297.

13. Scanning electron microscope photograph, $\times 2,500$, length $40 \mu \mathrm{m}$. From USGS diatom locality 7297.

14. Scanning electron microscope photograph, $\times 2,600$, length $33 \mu \mathrm{m}$. From USGS diatom locality 7293. 


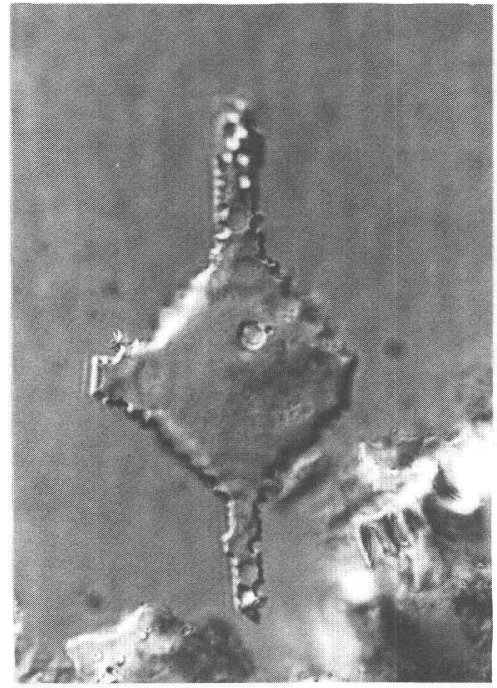

1

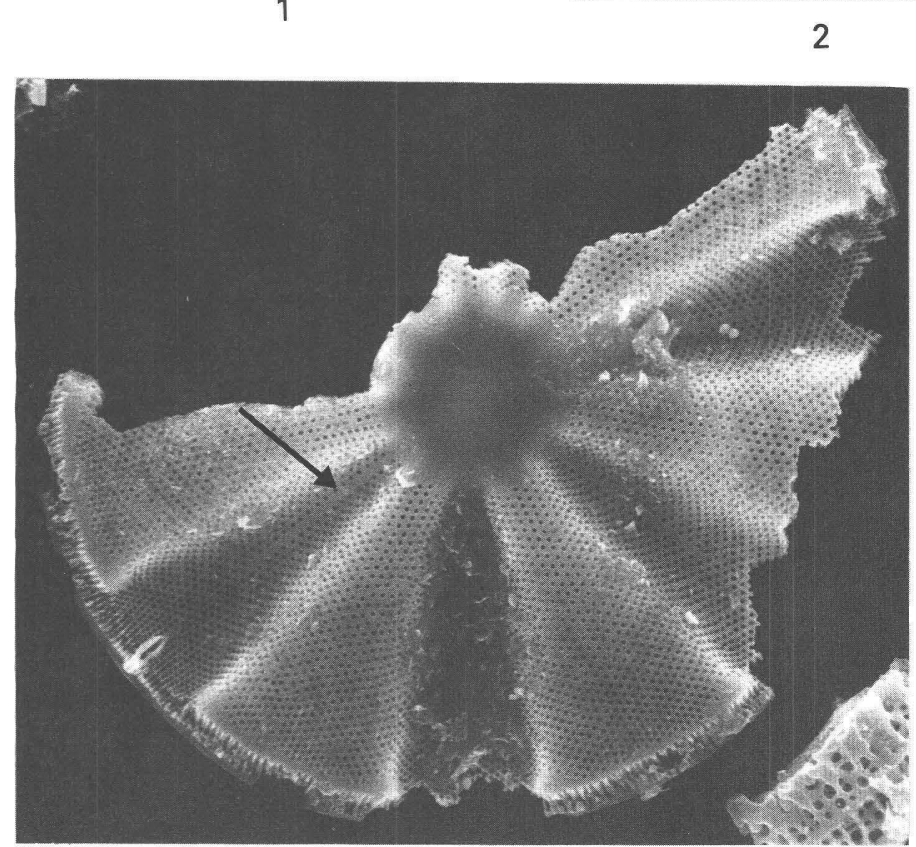

6

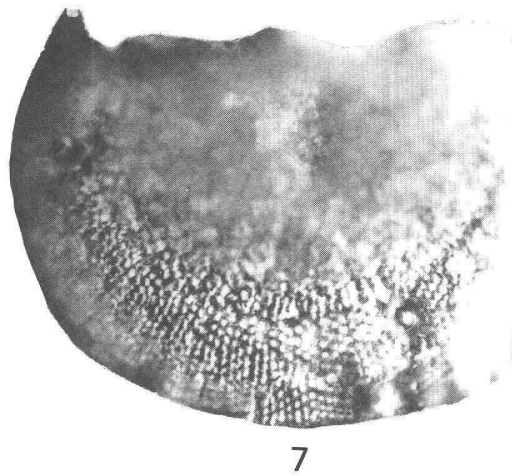

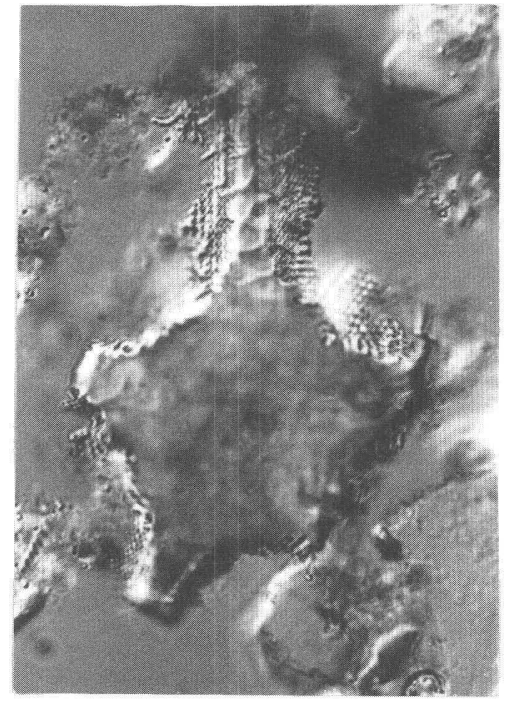

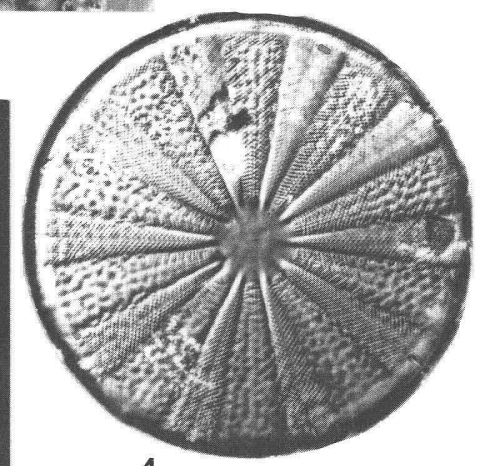

4

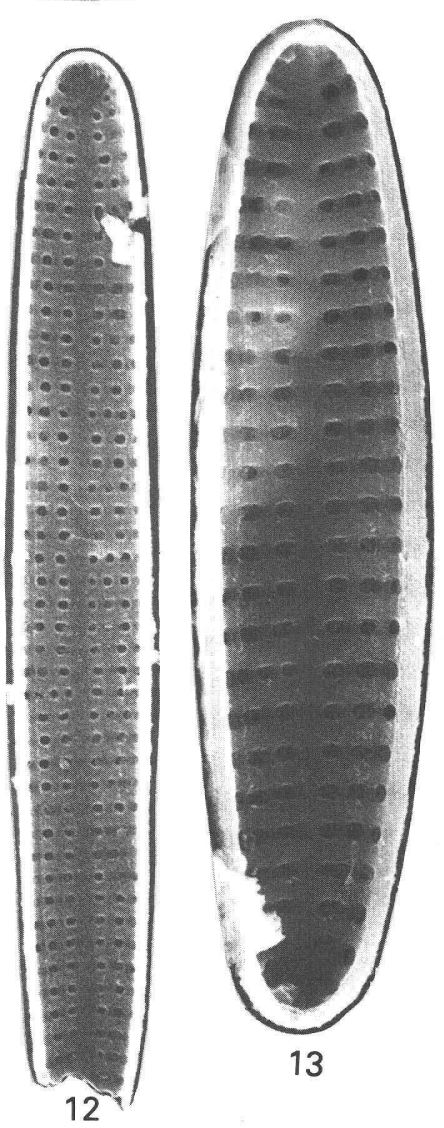

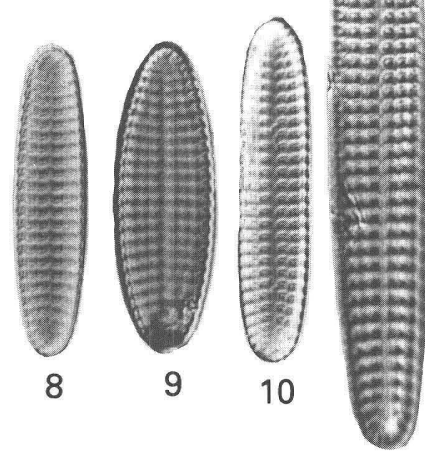

11

$$
12
$$

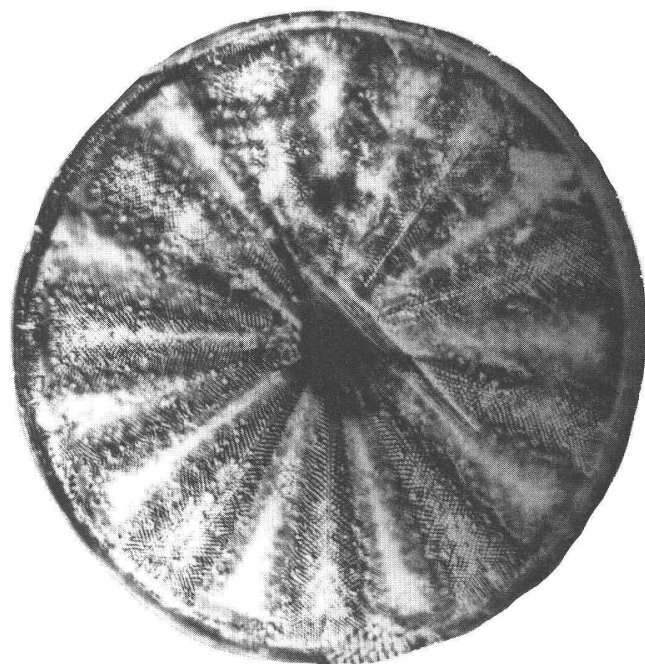

3
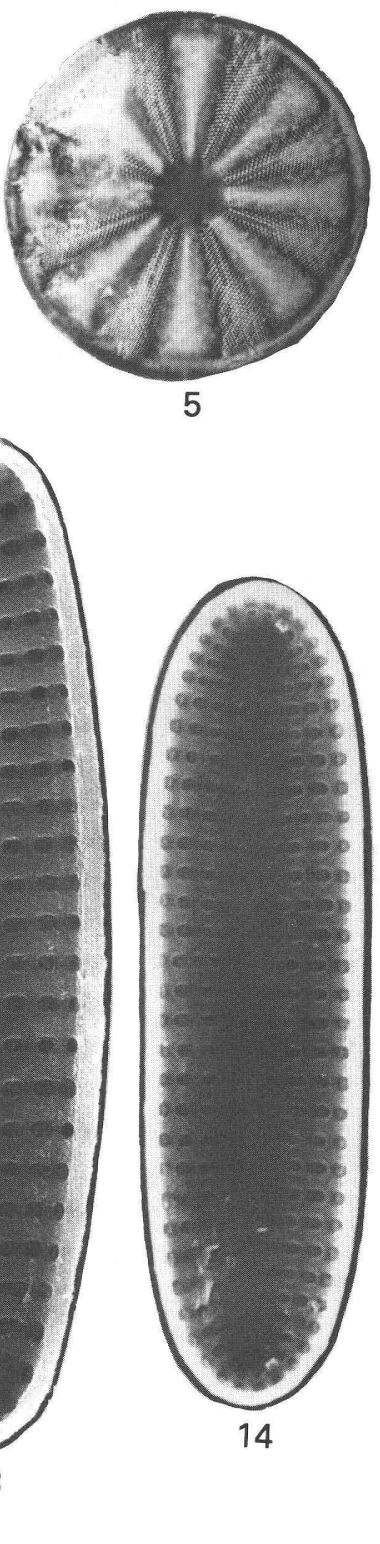


\section{PLATE 2}

Figure 1-4. Rhaphoneis fusiformis Andrews (p. 10).

1. USGS diatom cat. no. 4733-10, $\times 1,000$, length about $51 \mu \mathrm{m}$. From USGS diatom locality 7291.

2. USGS diatom cat. no. $4733-14, \times 1,000$, length $39 \mu \mathrm{m}$. From USGS diatom locality 7291.

3. Scanning electron microscope photograph, $\times 2,400$, length $44 \mu \mathrm{m}$. From USGS diatom locality 7293.

4. Scanning electron microscope photograph, $\times 2,000$, length $45 \mu \mathrm{m}$. From USGS diatom locality 7293.

5-12. Rhaphoneis margaritata Andrews (p. 10).

5. USGS diatom cat. no. 4734-3, $\times 500$, length $36 \mu \mathrm{m}$. From USGS diatom locality 7292.

6. USGS diatom cat. no. $4735-5, \times 500$, length $78 \mu \mathrm{m}$. From USGS diatom locality 7293.

7. USGS diatom cat. no. 4739-12, × 500, length $102 \mu \mathrm{m}$. From USGS diatom locality 7297.

8. USGS diatom cat. no. 4739-15, $\times 500$, length $120 \mu \mathrm{m}$. From USGS diatom locality 7297.

9. USGS diatom cat. no. 4739-7, × 500, length $140 \mu \mathrm{m}$. From USGS diatom locality 7297.

10. USGS diatom cat. no. 4736-6, $\times 500$, length $170 \mu \mathrm{m}$. From USGS diatom locality 7294.

11. Scanning electron microscope photograph, $\times 800$, length $147 \mu \mathrm{m}$. From USGS diatom locality 7297.

12. Scanning electron microscope photograph, $\times 1,000$, length $115 \mu \mathrm{m}$. From USGS diatom locality 7297.

13-19. Rhaphoneis praeparilis Andrews, n. sp. (p. 11).

13. Scanning electron microscope photograph, $\times 2,400$, length $42 \mu \mathrm{m}$. Transverse rows of areolae poorly ordered in center of valve. USGS diatom locality 7293 .

14. Scanning electron microscope photograph, $\times 2,400$, length $38 \mu \mathrm{m}$. USGS diatom locality 7293.

15. Scanning electron microscope photograph, $\times 1,500$, length $55 \mu \mathrm{m}$. USGS diatom locality 7293.

16. USGS diatom cat. no. 4739-14, $\times 1,000$, length $34 \mu \mathrm{m}$. USGS diatom locality 7297.

17. USGS diatom cat. no. 4736-3, $\times 1,000$, length $41 \mu \mathrm{m}$. USGS diatom locality 7294.

18. USGS diatom cat. no. $4739-8, \times 1,000$, length $46 \mu \mathrm{m}$. USGS diatom locality 7297.

19. Holotype, USGS diatom cat. no. $4735-7, \times 1,000$, length $50 \mu \mathrm{m}$. USGS diatom locality 7293.

20-23. Rhaphoneis scalaris Ehrenberg (p. 11).

20. Scanning electron microscope photograph, $\times 1,300$, length of fragment $76 \mu \mathrm{m}$. From USGS diatom locality 7293 .

21. USGS diatom cat. no. $4742-4, \times 1,000$, length of fragment about $80 \mu \mathrm{m}$. From USGS diatom locality 7300 .

22. USGS diatom cat. no. 4740-13, $\times 1,000$, length of fragment $78 \mu \mathrm{m}$. From USGS diatom locality 7298.

23. USGS diatom cat. no. $4741-7, \times 1,000$, length of fragment $76 \mu \mathrm{m}$. From USGS diatom locality 7298. 


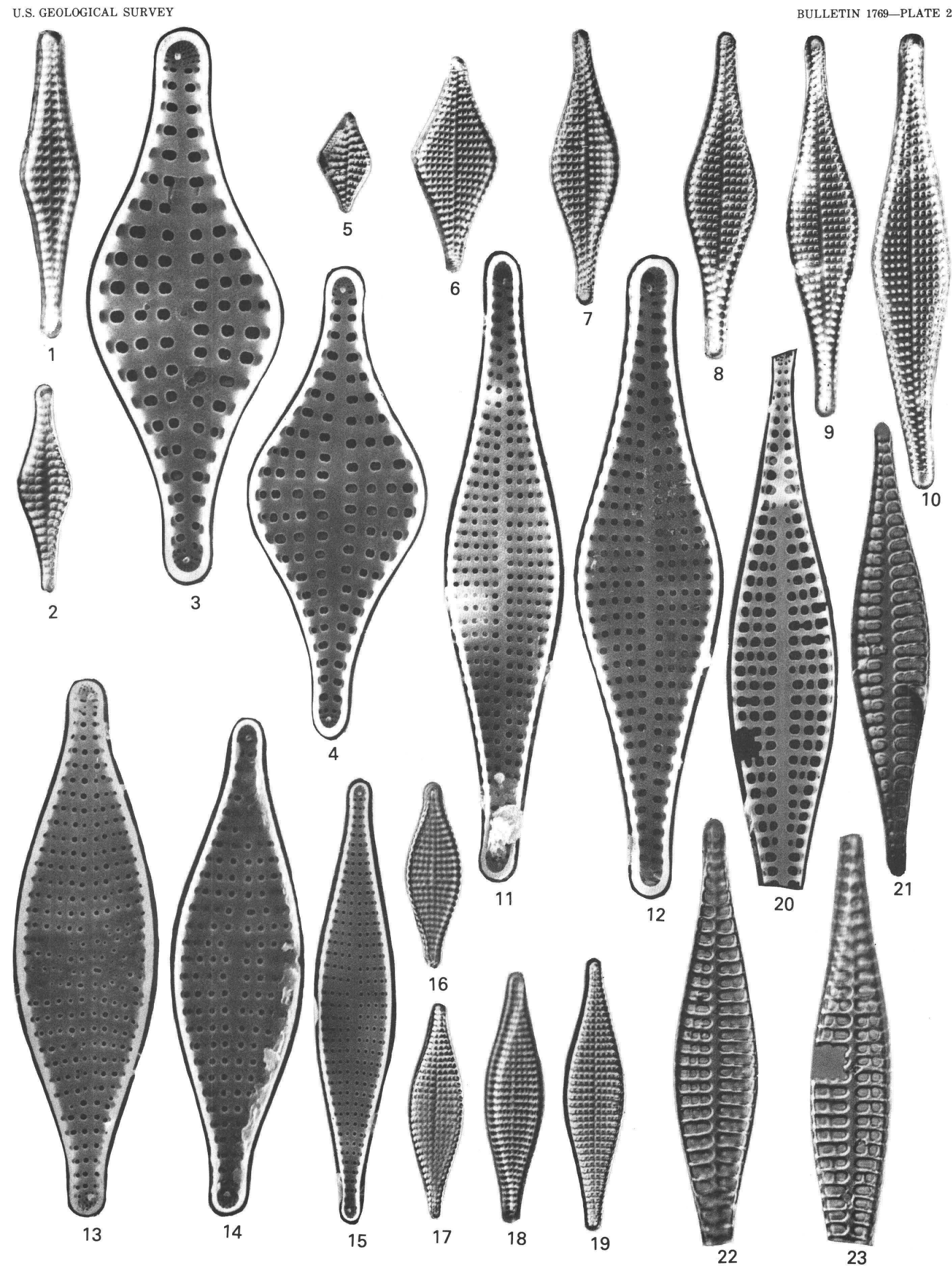




\section{PLATE 3}

Figure 1-5. Sceptroneis caduceus Ehrenberg (p. 11).

1. USGS diatom cat. no. 4741-2, $\times 1,000$, length of head-pole fragment 109 $\mu \mathrm{m}$. From USGS diatom locality 7299 .

2. USGS diatom cat. no. 4735-10, $\times 1,000$, length of head-pole fragment $105 \mu \mathrm{m}$. From USGS diatom locality 7293 .

3. USGS diatom cat. no. 4740-8, $\times 1,000$, length of head-pole fragment 63 $\mu \mathrm{m}$. From USGS diatom locality 7298 .

4. Scanning electron microscope photograph, $\times 1,700$, length of foot-pole fragment $67 \mu \mathrm{m}$. From USGS diatom locality 7297 .

5. Scanning electron microscope photograph, $\times 1,500$, length of foot-pole fragment $46 \mu \mathrm{m}$. From USGS diatom locality 7297 .

6, 7. Sceptroneis grandis Abbott ( $p .12$ ).

6. USGS diatom cat. no. 4734-13, × 1,000, length $120 \mu \mathrm{m}$. From USGS diatom locality 7292.

7. USGS diatom cat. no. $4733-3, \times 1,000$, length $114 \mu \mathrm{m}$. From USGS diatom locality 7291.

8. Sceptroneis hungarica (Pantocsek) Andrews (p. 12). USGS diatom cat. no. $4733-16, \times 1,000$, length of fragment $45 \mu \mathrm{m}$. From USGS diatom locality 7291.

9. Rhaphoneis scalaris Ehrenberg (p. 11). Scanning electron microscope photograph, inside of valve, $\times 2,500$, length of fragment $39 \mu \mathrm{m}$. From USGS diatom locality 7297.

10. Rhaphoneis margaritata Andrews (p. 10). Scanning electron microscope photograph, inside of end of valve, $\times 13,000$. From USGS diatom locality 7293.

11. Delphineis ovata Andrews (p. 10). Scanning electron microscope photograph, inside of end of valve, $\times 15,000$. From USGS diatom locality 7293.

12. Rhaphoneis praeparilis Andrews, $n$. $s p$. (p. 11). Scanning electron microscope photograph, inside of end of valve, $\times 15,000$. From USGS diatom locality 7293. 

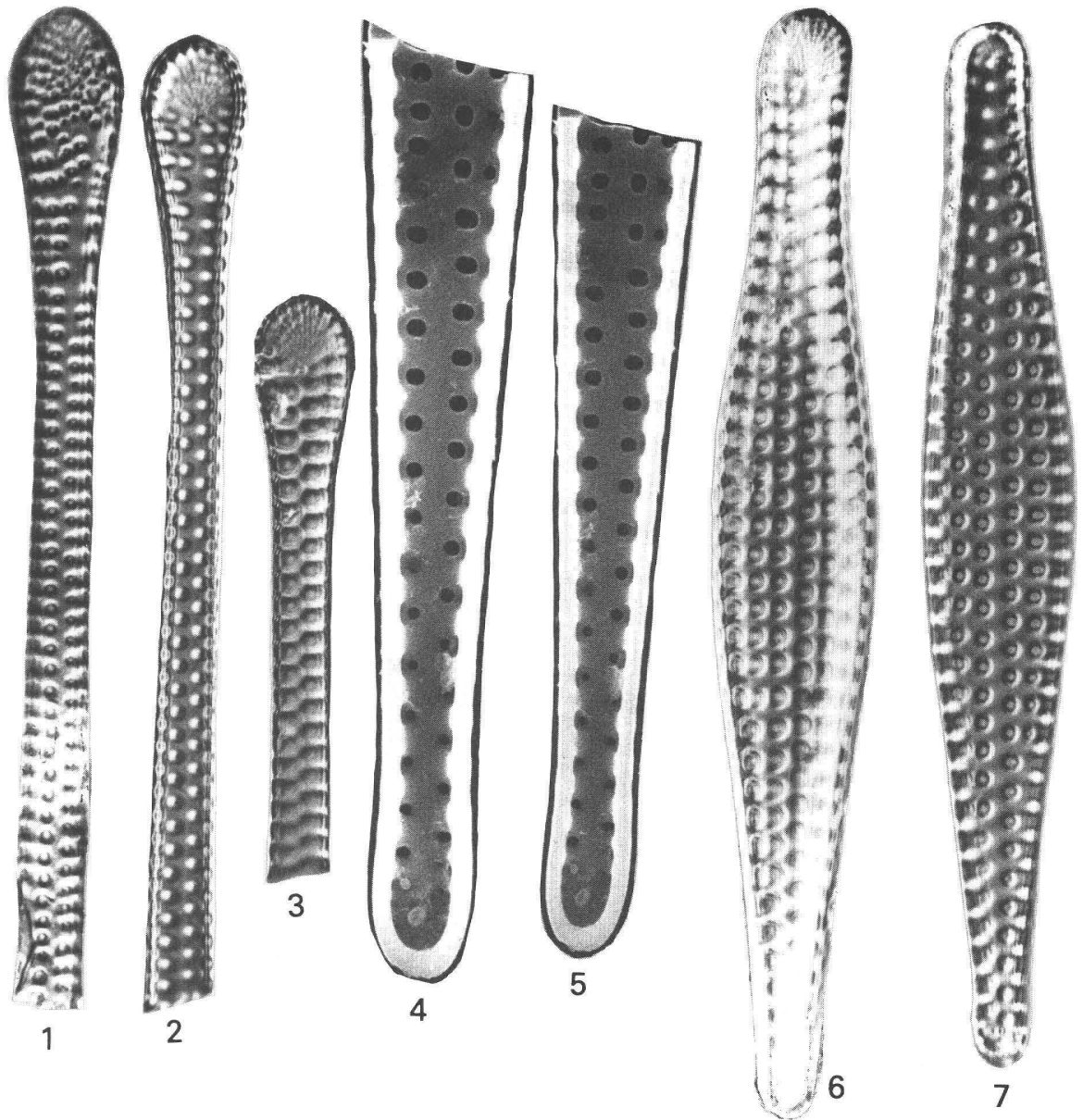

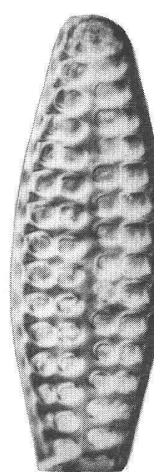

8
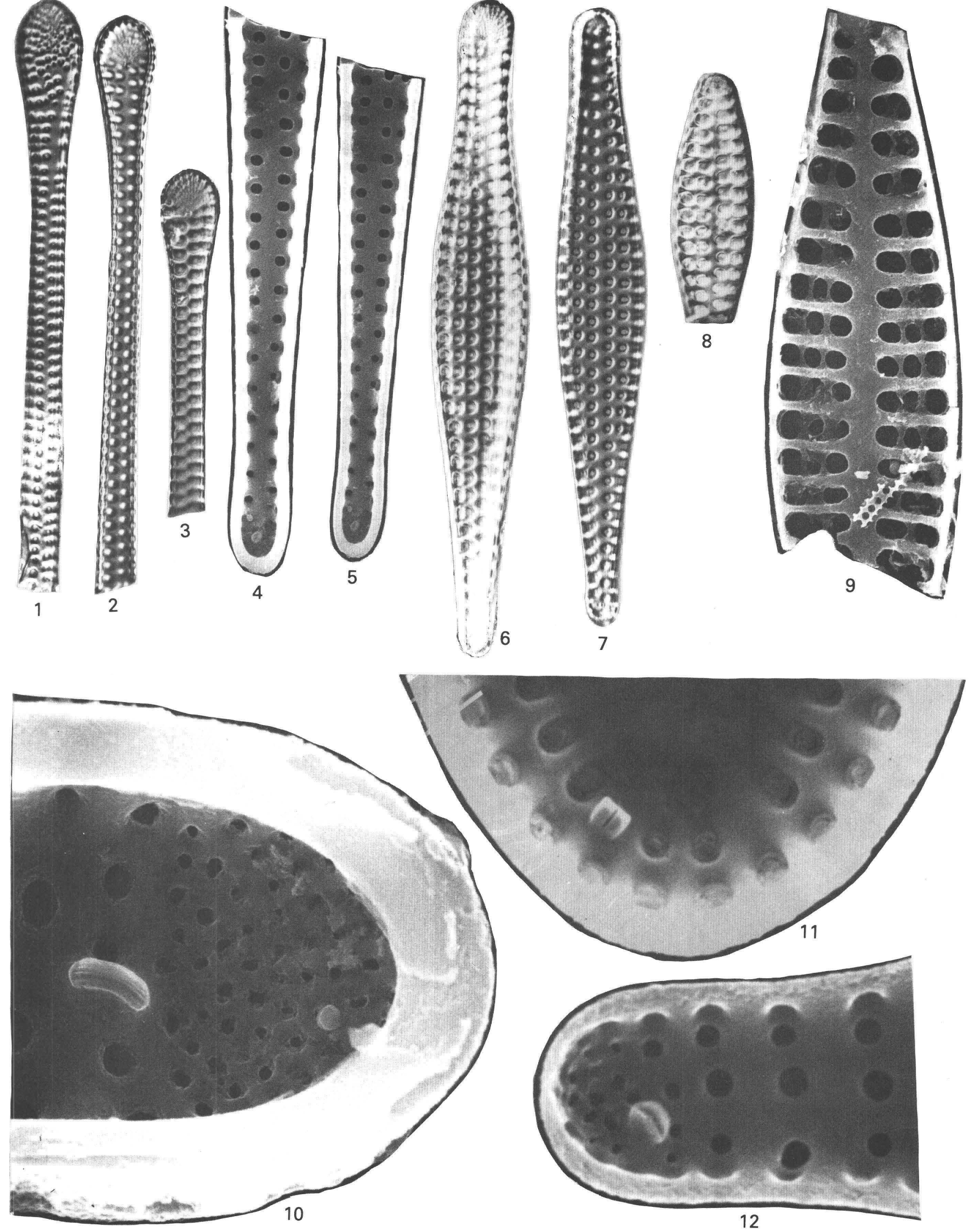

SCEPTRONEIS, RHAPHONEIS, AND DELPHINEIS 

